\title{
Amperometric Enzyme Electrodes
}

\author{
E.J. Calvo ${ }^{a^{*}}$, and C. Danilowicz ${ }^{b}$ \\ ${ }^{a} I N Q U I M A E$, Departamento de Química Inorgánica,Analítica y Química Física, \\ Facultad de Ciencias Exactas y Naturales, Universidad de Buenos Aires, Pabellon 2 \\ Ciudad Universitaria, AR-1428 Buenos Aires, Argentina; e-mail: calvo@q1.fcen.uba.ar \\ ${ }^{b}$ Facultad de Farmacia y Bioquímica, Universidad de Buenos Aires, Junin 956,
} AR-1113, Buenos Aires, Argentina

Received: June 24, 1997

\begin{abstract}
Neste trabalho de revisão são analisados os avanços mais recentes em eletrodos enzimáticos amperométricos dando ênfase particular aos biosensores baseados na Glucose Oxidase e na Horseradish Peroxidase. A intermediação redox através de mediadores artificiais solúveis ou ligados a polímeros é discutida em termos dos desenvolvimentos teóricos recentes e verificações experimentais. É analisada a dependência da resposta amperométrica com a concentração do substrato, do mediador e da enzima assim como com o potencial do eletrodo e a espessura do filme. São também avaliadas as possíveis aplicações destes sistemas em esquemas multi-enzimáticos.
\end{abstract}

Recent advances on amperometric enzyme electrodes are reviewed with particular emphasis on biosensors based on Glucose Oxidase and Horseradish Peroxidase. Redox mediation by artificial soluble and polymer attached redox mediators is discussed in terms of recent theoretical developments and experimental verification. The dependence of the amperometric response on substrate and mediator concentration, enzyme concentration, electrode potential and film thickness are analyzed. Possible applications in multienzyme schemes are also analyzed.

Keywords: biosensors, amperometric electrodes, enzime electrodes

\section{Introduction}

Biosensors are devices that combine the selectivity and specificity of a biological component with a suitable transducer. The biological sensing element, usually an enzyme or an antibody, recognizes the complementary molecule and the resulting biochemical changes are transduced into a concentration dependant proportional signal ${ }^{1}$.

Biosensor development began with experience of biomolecule immobilization and stabilization on the one hand, and the miniaturization and functionalization of more sophisticated transducers, on the other ${ }^{2}$.

The electronic transducer can frequently measure potential, current, light, temperature, mass, etc. Generally, biosensors can be classified according to the nature of the physical transducer: potentiometric, amperometric, calorimetric, piezoelectric or optical sensors.
Potentiometric devices measure potential under equilibrium conditions where no electrolysis and charge transport across the electrode-solution interface occur at the indicator electrode ${ }^{2}$. The potential difference between the indicator and the reference electrode is related to the analyte concentration according to the Nernst or the Donnan equation. Potentiometric measurements can involve an ion selective electrode or a noble metal electrode immersed in a solution of redox couple, modified with an immobilized selective protein ${ }^{3,4}$.

Amperometric biosensors are typically inexpensive and less critically dependent of an accurate reference electrode $^{5}$. In this case the potential at the working electrode is held constant while the current flow is measured. A simple circuit involves a two electrode configuration although more precise control of the applied potential can be achieved by using a potentiostat and a three electrode configuration ${ }^{6}$.

* Permanent Research Staff of CONICET (Argentina) 
Calorimetric biosensors are used when the reaction involves important energy conversion, generally, heat production. This heat leads to a proportional temperature rise which can be related to the analyte concentration. Some early publications appeared in $1974^{7}$ and general review articles have appeared in recent years ${ }^{8}$.

Piezoelectric devices require an oscillating crystal subjected to an alternating frequency $(\mathrm{MHz})$. The mechanical oscillation of the crystal varies according to mass changes. The crystals are modified with biomolecules exhibiting high selectivity towards the substance to be determined. The principal disadvantage of these devices depends on nonselective adsorption. Some alternatives have been proposed in order to overcome this effect ${ }^{9-12}$.

Optical sensors, known as optodes, have achieved significant innovations by using optical fibre. When the biochemical process determines an optical effect the resulting signal can be transmitted with an optical fibre. Different configurations and examples of optical sensors can be found in the literature ${ }^{13,14}$.

\section{Enzymatic electrodes}

Biosensors are called enzymatic electrodes when an enzyme is the biological component and transduction is based on electrochemical principles. This type of biosensor now plays an important role, in particular, for biomedical and technological applications ${ }^{15}$.

Enzymes are proteins which present an outstanding ability for molecular recognition. The biochemical changes following this process are finally electrochemically transduced.

Many enzymes have been characterized, particularly with respect to tertiary structure and are also commercially available. Therefore, it is not surprising that a great majority of the biosensors, so far described, are based on enzymes $^{2}$.

Redox enzymes, called oxido-reductases, are probably the most frequently employed. They are classified with regard to the prosthetic group, a molecule tightly bound to the protein structure: flavin, quinone, heme or copper center.

More than 80 flavin enzymes are known with FAD (flavin adenine dinucleotide) or FMN (flavin adenine mononucleotide) covalently or tightly attached. The active redox site of this molecule corresponds to the isoalloxacine group and the redox process depends strongly on $\mathrm{pH}$.

The redox potential of FAD has been studied in different enzymes and depending on the protein structure, it varies between -730 and $-50 \mathrm{mV}$ vs. $\mathrm{SCE}^{16,17}$.

The enzymes which contain quinones as prosthetic group, called quinoenzymes, are less common. The redox active group is 2,7,9-tricarboxy- $1 \mathrm{H}$ - pyrrolo- (2,3-quinoline-4,5-dione) known as PQQ and since oxygen does not reoxidise it, they are dehydrogenases. Quino enzymes used in electrochemical studies include alcohol dehydrogenase and glucose dehydrogenase ${ }^{18,19}$.

\section{Glucose oxidase}

The enzyme glucose oxidase $(\beta-\mathrm{D}$ glucose oxygen 1 oxide reductase EC 1.1.3.4) discovered by Muller in 1928 has been used in most of the work on biosensors.

It can be obtained from Aspergillus niger and Penicillium notatum. It catalyses $\beta$-D glucose oxidation in the presence of oxygen producing D-gluconolactone, which hydrolyzes to gluconic acid, and hydrogen peroxide.

This enzyme is a homodimer of 150 to $186 \mathrm{kDa}$ molecular weight which contains two FAD molecules tightly bound. With denaturing agents, both subunits can dissociate leading to FAD loss ${ }^{20}$.

The primary structure has been described from the c-DNA sequence corresponding to 583 aminoacids, 3 cysteine residues and 8 potential sites for $\mathrm{N}$-linked glycosilation $^{21}$. A high negative charge at neutral $\mathrm{pH}$ can be predicted from this information. The enzyme is a glycoprotein which contains 10 to $16 \%$ carbohydrate, manose being the most abundant ${ }^{22}$.

The monomeric molecule is a compact spheroid with dimensions $60 \AA$ x $52 \AA$ x $37 \AA$ and the dimensions for the dimer are $60 \AA$ x $52 \AA$ x $77 \AA$.

The secondary structure has also been studied with regard to FAD and substrate binding sites ${ }^{23}$.

Oxygen is the natural co-substrate of GOx. It reacts producing hydrogen peroxide which, as it has been studied, affects the enzyme, particularly the oxidized form of $\mathrm{GOx}^{24}$. In living organisms hydrogen peroxide is eliminated by catalase. Another drawback for this type of biosensor is that either the detection of oxygen decrease or hydrogen peroxide at high positive potentials can lead to the oxidation of interfering species.

An improved alternative is the use of an oxidizing species other than oxygen ${ }^{25,26}$. The signal detected depends on the oxidation of these species, called mediators, according to

$$
\begin{aligned}
& \mathrm{R} \longrightarrow \mathrm{O}+\mathrm{ne}^{-} \\
& \text {EnzRed }_{\text {R }} \mathrm{O} \longrightarrow 2 \mathrm{R}+\mathrm{Enz}_{\mathrm{Ox}} \\
& \text { EnzOx }+\mathrm{S} \longrightarrow \text { EnzRed }_{\mathrm{R}} \mathrm{P}
\end{aligned}
$$

where $\mathrm{O}$ is a one electron redox couple.

These mediators can be classified in four groups depending on the optimum working $\mathrm{pH}^{27}$ :

- Those for which optimum $\mathrm{pH}$ is 5,6 such as quinones.

- Compounds like p-phenylenediamine, phenoxazines like methylene blue and toluidine blue, ferrocenes, tetrathiafulvalene (TTF), tetracyanoquinodimethane (TCNQ) and benzylviologen. 
- Compounds with a high charge density that have an acidic optimum $\mathrm{pH}$.

- Compounds with low charge density that have also an acidic optimum $\mathrm{pH}$ like indophenols.

Certain criteria must be satisfied when choosing a mediator, such as $^{28}$ :

- Rapid reaction with the enzyme and the electrode; chemical stability under experimental conditions; no secondary reactions should be involved.

- It must present a redox potential away from the redox potential of interfering species.

- The potential should be independent of $\mathrm{pH}$.

- It should be preferably non toxic and amenable to immobilization on the electrode.

The design of amperometric biosensors involves several strategies. These can be divided into two main groups: those which require a soluble enzyme and those where the enzyme is immobilised at the electrode surface. In both cases oxygen can be replaced by a redox mediator.

Experiments with soluble enzymes can be further classified according to the use of redox mediator which can be soluble, bound to the enzyme structure or immobilized at the electrode surface.

The first alternative has been extensively studied and is called homogeneous mediation. The enzyme and the mediator are free in solution. The mediator is oxidised (reduced) at the electrode and diffuses into the solution where it reacts with the enzyme. Therefore the reduced (oxidised) mediator diffuses back towards the electrode to complete the cycle.

It is possible to find a large number of examples, particularly for GOx, involving different mediators such as ferrocenes ${ }^{29-32}$, ruthenium complexes ${ }^{33}$ and quinones ${ }^{34,35}$.

These studies have contributed to the understanding of amperometric biosensors. However, there are several disadvantages, in particular, the fact that this type of device cannot be used as an implantable biosensor.

An attractive alternative is the modification of redox enzymes with mediators covalently attached to the protein structure. This is not significantly different from the previous situation since the mediator is bound to the enzyme but the latter is still in solution. However, if the enzyme is prevented from diffusing freely by using semipermeable membranes, the mediator will also be confined to a thin adyacent solution layer adacent to the electrode.

Several publications describe the attachment of redox molecules such as ferrocenecarboxylic acid and other ferrocene derivatives to $\varepsilon$-amine groups of GOx proving electronic transfer to FAD molecule ${ }^{36}$.

Heller et al. have modified enzymes like GOx and D-aminoacid oxidase with ferrocenecarboxylic acid, ferroceneacetic and ruthenium complexes such as ruthenium pentamine-nicotinic acid and have shown a catalytic effect upon substrate addition ${ }^{37}$. However, this electrode design has presented poor stability. Further work involved ferrocene attachment to oxidized carbohydrate residues on the enzyme outer surface ${ }^{38}$. In this case effective intramolecular communication between the FAD group and the mediator required longer spacer chains to allow ferrocene to penetrate sufficiently to approach the enzyme redox site. When the modified enzyme was immobilised onto a graphite electrode negligible currents were detected. These results suggested that electron transfer involving redox relays, GOx redox site and the electrode required freely tumbling enzyme molecules ${ }^{39}$.

Bartlett et al. have also modified GOx enzyme using ferrocene derivatives and have also observed continuous signal loss which was attributed to ferrocene decomposition in accordance to Szentrimay's studies ${ }^{40-42}$.

A detailed study of GOx modification can also be found in a publication of English et al..$^{43}$ In this work covalent derivatization of glucose oxidase with ferrocene derivatives was evaluated by following the quenching of tryptophan fluorescence. The results of voltammetric dilution experiments were also consistent with intramolecular electron transfer between FAD and mediator moieties. The values calculated for electron transfer rate constants were small and allowed to the estimation of the average redox site separations as 21 and $26 \AA$. It is suggested that enhanced electron transfer rates should be expected if acid residues were modified.

More recently Bartlett $e t$ al. have reported the covalent modification of GOx with a tetrathiafulvalene derivative. These results show that the oxidized tetrathiafulvalene derivative can oxidize the enzyme and that the stability of GOx is significantly improved upon covalent modification $^{44}$.

Electron exchange between soluble redox enzymes and immobilised mediators was achieved when using conducting organic salts. These materials are prepared by combining a suitable organic electron donor and acceptor molecules. A typical example corresponds to the combination of tetrathiofulvalene and tetracyanoquinodimethane (TTF.TCNQ). Other combinations used for GOx are NMP.TCNQ, Q.TCNQ, Fc.TCNQ, NMA.TCNQ where NMP is N-methyl phenazine, $\mathrm{Q}$ is quinoline, $\mathrm{Fc}$ is ferrocene, NMA is N-methylacridine, respectively ${ }^{45,46}$. It is proposed that direct electron transfer from the modified electrode to the enzyme may occur and a mechanism for this interaction was presented ${ }^{47}$.

The other main group involves enzyme immobilization. In this case three alternatives emerge: direct communication between electrode and enzyme which implies no redox mediator; soluble redox mediators and immobilised mediators.

Direct electron transfer from an electrode to an enzyme active site seems to simplify biosensor design. In this case 
no co-substrate nor mediator is required and enzyme electrochemical oxidation (reduction) determines the amperometric signal. However, some aspects must be taken into account when considering this possibility. It should be pointed out that successful results, with regard to electron transfer, were obtained with redox proteins. These molecules usually presenting 5 to $15 \mathrm{kDa}$ molecular weight exhibit redox sites at the periphery of the protein structure.

The redox centre may approach sufficiently close to the electrode to allow rapid electron transfer. The dependence of electron exchange on distance has been studied in these proteins and other biological molecules ${ }^{48,49}$. It represents a critical factor when dealing with redox enzymes. These molecules are generally higher molecular weight proteins and have an active site deeply buried within the protein structure.

Although negative results for GOx were initially reported $^{50}$, Bockris et al. observed direct electron transfer to this protein with differential pulse measurements ${ }^{51}$. GOx was adsorbed at graphite electrodes which probably resulted in partial enzyme unfoulding, allowing FAD molecules to contact the electrode surface. Direct electron exchange resulted for low enzyme concentrations and anodic current increased upon substrate addition up to $1 \mathrm{mM}$.

Elipsometric studies for GOx adsorption on gold concluded that GOx adsorbed in three stages leading finally to slow unfolding of the enzyme with loss of tertiary structure $^{52}$.

Wingard et al. have tried different alternatives to communicate with GOx redox site. Some of them were unsuccessful $^{53,54}$ and only when an (aminophenyl)boronic acid modified glassy carbon electrode was used, direct electron tranfer could be demonstrated ${ }^{55}$. The electrode surface is oxidized and the resulting carboxylic groups are made to react with aminophenyl boronic acid by aqueous soluble carbodiimide. The resulting modified electrodes are further immersed in GOx solution. The authors demonstrate that electron transfer occurs with FAD still attached to the enzyme and not due to free FAD. However, they fail to explain how this process occurs and the lack of catalytic response when glucose is added.

There are several examples involving soluble mediator and immobilized enzymes. Most of the experience on protein immobilization was applied to electrode design ${ }^{56}$. Early reports used dialysis membranes ${ }^{57}$ and some years later hydrogels appeared to be a better choice ${ }^{58-62}$. A large number of reports can be found involving enzymes physically or covalently entrapped ${ }^{63-72}$.

An attractive approach for enzyme immobilization is electrochemical polymerisation. This is a simple procedure where a suitable monomer is oxidized in the presence of an enzyme. The resulting polymer can be conducting or nonconducting depending on the monomer employed. The enzyme is confined to a layer adacent to the electrode. The film thickness can be easily controlled by adjusting the applied potential. In this way biosensors are designed with one or several layers ${ }^{73}$ or with several enzymes in one or more layers $^{74}$.

The majority of the published work involves the use of pyrrole and derivatives to entrap $\mathrm{GOx}^{75-79}$ and other enzymes such as poly(phenol)oxidase ${ }^{80}$, cholesterol oxidase $^{81}$ and horseradish peroxidase ${ }^{82}$.

Pyrrole can be readily polymerized at potentials greater than $600 \mathrm{mV} v s$. SCE by working at fixed potential or by using cyclic voltammetry. The physical properties of the film depend on the nature of the electrode used, the rate of polymerization, the ionic species present and the solution $\mathrm{pH}$.

Monomeric and dimeric cationic radicals are initially generated leading to oligomer formation which can in turn deposit as polymeric chains on the electrode. It must be taken into account that during this process the $\mathrm{pH}$ decreases near the electrode, therefore buffer solutions must be used to avoid enzyme denaturation.

It has been proposed that GOx, presenting highly negative charge at $\mathrm{pH} 7$, is electrostatically entrapped among polymer chains which allows enzyme immobilization ${ }^{83}$. This was demonstrated with several experiments: GOx can be adsorbed onto polypyrrole films ${ }^{84}$, the amount of entrapped enzyme decreases in the presence of competing anionic molecules such as sulphonated hydroquinone ${ }^{85}$ and ferrocyanide $^{79}$ and it is very difficult to entrap positively charged proteins.

Covalent attachment to preformed polymeric films has also been described ${ }^{86}$.

The amperometric signal in these electrodes is obtained with redox mediators or with the natural co-substrate, oxygen. In this latter case the resulting product, hydrogen peroxide, affects polypyrrole structure ${ }^{87}$. Another disadvantage results from the fact that the applied potential $(0.65 \mathrm{~V} v s . \mathrm{Ag} / \mathrm{AgCl})$ is susceptible to the presence of interfering compounds like ascorbic acid and uric acid. Redox mediators are used instead of oxygen and in some cases they have been co-immobilized with the enzyme $^{85,88}$. The kinetic behaviour of this type of biosensor has been studied and several works suggest models to describe these systems ${ }^{89,90}$.

Other conducting polymers have been employed for enzyme immobilization such as poly(thiophenes) ${ }^{91}$, poly(indoles) $)^{92}$ and poly(aniline $)^{93,94}$. However, these electropolymerizations present serious disadvantages. The former require aprotic solvents and the latter need strongly acidic solutions (around pH 1).

Another interesting alternative is the use of non-conducting polymers such as polyphenols. The resulting films are thin (50 to $100 \mathrm{~nm}$ ), hydrophobic and insulating ${ }^{95}$. These thin films allow rapid diffusion of substrate and product and exhibit selectivity towards interfering spe- 
$\operatorname{cies}^{96}$. The polymerization of phenols proceeds in a similar way to that for polypyrrole. The resulting films are generally continuous and free from defects which has been evaluated following ferro-ferricyanide voltammetry ${ }^{89}$. A simple model has been proposed to analyse the glucose/enzyme kinetics $^{96}$.

Non-conducting films have also been obtained with 1,2 diamino benzene ${ }^{97-99}$.

A different strategy for enzyme immobilization is covalent attachment to modify electrode surfaces in order to obtain enzyme monolayers. The most popular methods are the use of reactive silanes ${ }^{100}$. Another similar method is to modify an electrode with cyanuric chloride ${ }^{101-102}$. A second step requires the attachment of an alcohol or amine. Carbon surfaces can be functionalized after surface oxidation. The resulting carboxylic groups can be activated with thionyl chloride or carbodiimides ${ }^{103}$ which can be finally used to anchor biomolecules.

A promising strategy in biosensor design is the immobilization of both enzyme and mediator which generally requires polymeric matrices. Different redox polymers have been used where redox molecules are bound to polymeric chains. Most of the examples involve redox organic molecules or transition metal complexes which can be reversibly oxidized or reduced ${ }^{104}$.

In this case the electrode and the redox enzyme are electrically connected through the redox polymer and charge can be transported from and to the electrode. Figure 1 shows a simplified model for a hydrogel modified enzyme electrode mediated by a redox polymer, where $\mathrm{k}_{\mathrm{s}, \mathrm{i}}$ and $\mathrm{k}_{\mathrm{s}, \mathrm{e}}$ represent the mass transport coefficients within the hydrogel layer of thickness 1 and in the external electrolyte, respectively.

Redox polymers fall into three categories according to the type of attachment of the redox centres to the polymer backbone: covalent, coordinative or electrostatic ${ }^{105}$. These materials have been frequently used to design modified electrodes. The use of redox polymers in biosensor design

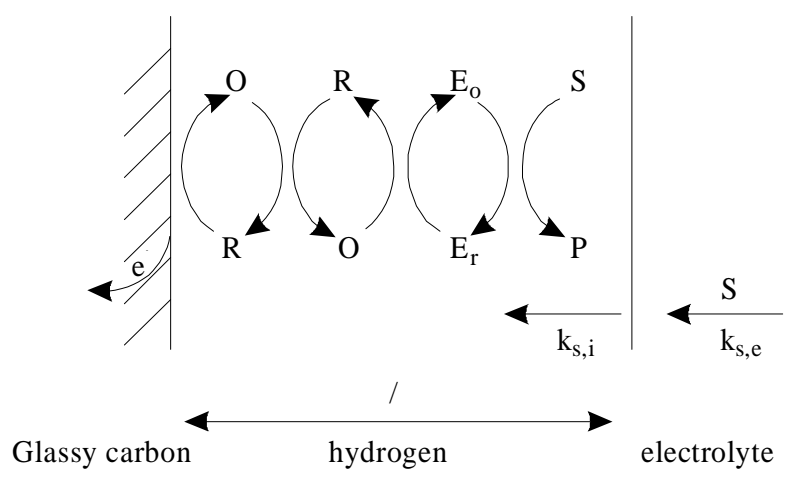

Figure 1. Schematic representation of the double catalytic redox-enzymatic cycle for the transformation of substrate by the enzyme with redox mediated electron transfer to the electrode. From. Ref. 128 (Royal Society of Chemistry) seems to be an attractive alternative to effect electron transfer between an enzyme and an electrode. Free diffusion of enzyme and mediator is avoided and consequently the resulting device is ideal as an implantable sensor.

Initial results allowed the conclusion that a flexible polymeric structure would be necessary in order to access the enzymatic redox site. Preliminary experiments with polyvinylferrocene were unsuccessful probably due to a rigid polymeric structure ${ }^{106}$.

A different application of polyferrocenes was reported by Turner et al. showing effective mediation with glucose oxidase $^{107}$. The polyferrocene mediators were initially deposited onto the electrode surface and after thoroughly drying GOx was finally immobilized. A similar electrode design was reported by Savinell et al. ${ }^{108}$ Polyvinylferrocene deposited on disk electrodes was used as a polymeric mediator and electro-oxidized in a GOx solution for enzyme immobilization.

An attempt to improve these results was proposed by Hale et al. who reported the use of polysiloxanes in several works $^{109-112}$. Polysiloxanes with flexible chains due to a low rotational energy proved to be effective for redox mediation. The optimization of the response depended on ferrocene content, chain mobility ${ }^{110,111}$ and the length of the alkyl side chains containing the active redox group ${ }^{112}$. However, these redox polymers were only soluble in organic media and therefore two separated steps were required to introduce the polymer and the enzyme on the electrode surface.

Amperometric glucose electrodes with other polymers such as ferrocene attached to poly L-lysine were prepared by simultaneous immobilization of polymer and enzyme with a semipermeable membrane ${ }^{113}$.

Heller et al. proposed a different fruitful strategy by working with soluble redox hydrogels like polyvinylpyridine modified with osmium complexes as redox mediators ${ }^{36}$. The enzyme GOx was initially immobilized in a two dimensional structure through electrostatic complexation on the electrode or covalent attachment to tyrosine residues ${ }^{114}$. This polymer effectively catalysed glucose oxidation when adsorbed onto a graphite electrode ${ }^{115}$.

Three dimensional enzyme wiring was accomplished when working with redox macromolecules. The design of these macromolecules assured that they would complex the enzyme and enable electron transfer from the buried redox site to the periphery of the enzyme. The redox macromolecule should present opposite charge to the enzyme but also hydrophobic or hydrogen bonding domains to adequately bind domains of the enzyme protein. The formation of adducts between polyelectrolytes and enzymes was studied through controlled variation of the isoelectric point of recombinant glucose oxidase ${ }^{116}$. The molecular weight should be high so as to adsorb onto the electrode surface with most segments remaining unadsorbed and thus avail- 
able to complex the enzyme. The redox macromolecule should connect multiple enzyme layers so that increased current densities can be obtained $^{39}$, see Fig. 2

It is possible to estimate the resulting signal when one GOx monolayer is densely packed on a $1 \mathrm{~cm}^{2}$ surface. For each enzyme molecule $10^{3}$ substrate molecules per second are oxidized and 2 electrons are transferred. Thus considering that the enzyme has $10^{2} \AA$ diameter, there are $1,3 \mathrm{x}$ $10^{12}$ molecules per $\mathrm{cm}^{2}$ and 2,6 $\times 10^{15}$ electrons can be transferred resulting a maximum current of $4.10^{-4} \mathrm{~A} \mathrm{~cm}^{-2}$ 39. It should be noted, however, that considerably lower currents are obtained experimentally even for fully active enzyme monolayer; a this can be related to mediator-enzyme orientation factors.

Three dimensional networks that electrically connect enzyme redox centres to electrodes were achieved when using diepoxide as crosslinking agent. The first step involves complex formation by mixing enzyme and redox

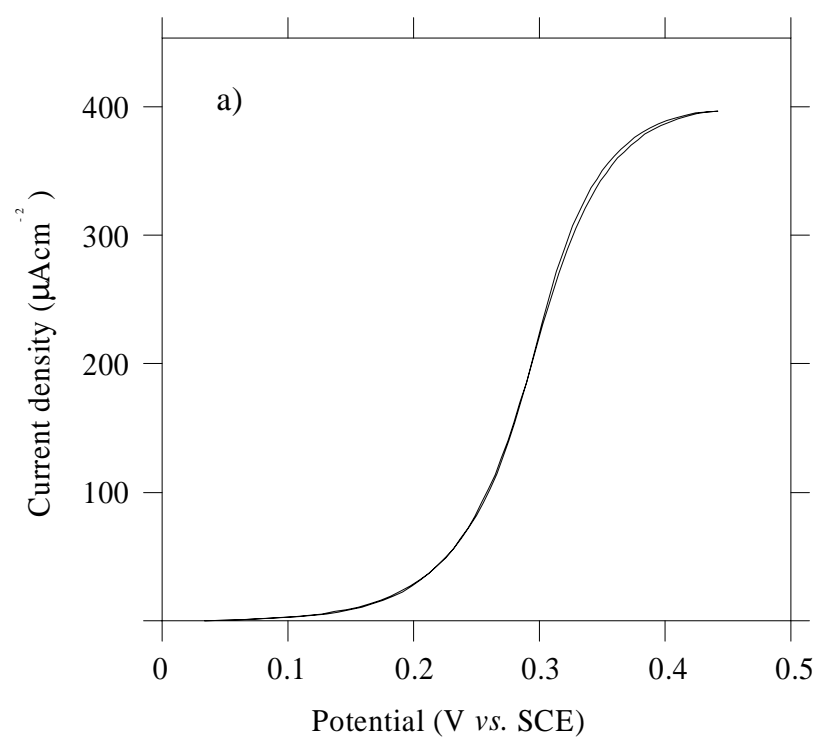

(b)

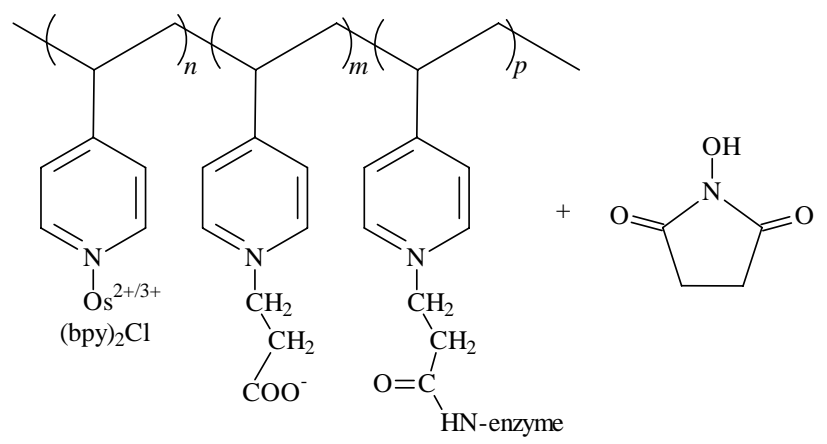

Figure 2. Catalytic wave for the oxidation of glucose by the enzyme glucose oxidase "wired to the electrode" by the redox polymer (shown in Fig 2b) crosslinked to the enzyme. After Heller, from Ref. 36 (American Chemical Society). polymer solutions. Finally, covalent crosslinking requires diepoxide addition. This allowed large current densities in the presence of freely diffusing substrate under anaerobic conditions $^{117-119}$. When a layer of immobilized peroxidase was added, it was possible to eliminate interfering effects due to ascorbic acid, urate and acetaminophen ${ }^{120,121}$.

Most of the work was carried out with GOx although several other enzymes could also be electrically "wired" 122,124

More recently, polyvinylimidazole modified with osmium complexes, presenting less positive oxidizing potentials, was used as a redox hydrogel ${ }^{125,126}$. This redox polymer was therefore used in the design of a selective subcutaneously implantable glucose electrode. The sensor presented no leachable components, high stability and a clinically relevant concentration range ${ }^{127}$.

A theoretical framework for the kinetic analysis of reagentless amperometric enzyme electrodes was proposed and the model was validated with experimental results ${ }^{128}$.

The redox enzyme catalytic cycle for the anaerobic oxidation of glucose substrate, $\mathrm{S}$, by redox cosubstrate attached to the polymer backbone, $\mathrm{O}$, catalysed by the enzyme in the hydrogel can be represented by Eqs. 1 to $4^{128}$ :

$$
\begin{aligned}
& \mathrm{R} \longrightarrow \mathrm{O}+\mathrm{e} \\
& \mathrm{E}_{0}+\mathrm{S} \rightleftharpoons \mathrm{E}_{\mathrm{R}}-\mathrm{S} \longrightarrow \mathrm{E}_{\mathrm{R}}+\mathrm{P} \\
& \mathrm{GOx}\left(\mathrm{FADH}_{2}\right)+\mathrm{O} \underset{\mathrm{GOx}(\mathrm{FADH} \bullet)+\mathrm{R}+\mathrm{H}^{+}}{\longrightarrow} \\
& \mathrm{GOx}(\mathrm{FADH} \bullet)+\mathrm{O} \underset{\mathrm{GOx}(\mathrm{FAD})+\mathrm{R}+\mathrm{H}^{+}}{\longrightarrow}
\end{aligned}
$$

The concentrations of oxidized and reduced redox sites in the polymer, soluble substrate and the different forms of enzyme entrapped in the gel layer are described by $\mathrm{c}_{\mathrm{O}}, \mathrm{c}_{\mathrm{R}}$, $\mathrm{c}_{\mathrm{S}}, \mathrm{c}_{\mathrm{EO}}, \mathrm{c}_{\mathrm{ER}}$ and $\mathrm{c}_{\mathrm{ET}}$, respectively. Electrode reaction (1) takes place at the electrode-gel interface with fast kinetics.

In this case direct electrical communication between a new acrylamide-acrylic acid ferrocene copolymer and GOx was achieved $^{128}$. The redox polymer also proved effective mediation with horseradish peroxidase which can be seen in Fig. 3 and the scheme of reactions involved is ${ }^{128}$ :

$$
\begin{aligned}
& \mathrm{H}_{2} \mathrm{O}_{2}+\mathrm{HRP}_{(\text {red })} \longrightarrow \mathrm{H}_{2} \mathrm{O}+\mathrm{HRP}_{(\text {ox })} \\
& \mathrm{HRP}_{(\text {ox })}+2 \mathrm{R} \longrightarrow \mathrm{HRP}_{(\mathrm{red})}+2 \mathrm{O} \\
& 2 \mathrm{O}+2 \mathrm{e} \longrightarrow 2 \mathrm{R}
\end{aligned}
$$

The redox polymer oxidizes $\mathrm{FADH}_{2}$ in GOx and reduces an haemporphyrin in peroxidase. However, in both cases low catalytic currents were observed for the acrylic hydrogel.

Heller et al. obtained larger currents with acrylamide and vinylimidazole copolymers containing osmium redox sites $^{129}$. In this work several oxidases were electrically 


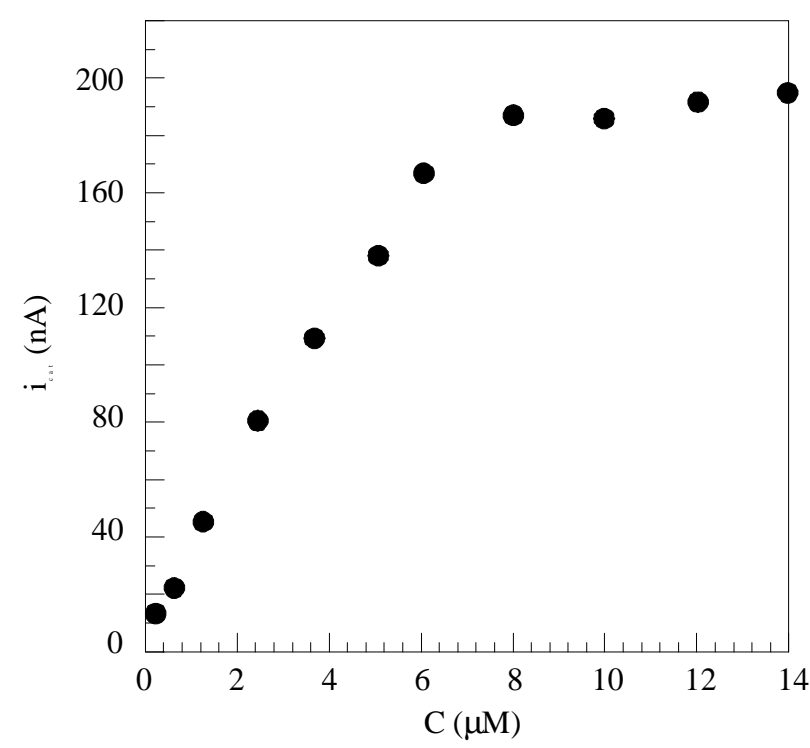

Figure 3. Steady-state catalytic response for the reduction of $\mathrm{H}_{2} \mathrm{O}_{2}$ at Fc-Poly (acrylamide) modified electrode as a function of substrate concentration. $\mathrm{E}=0.15 \mathrm{~V} v s$. SCE. Rotation frequency $2.8 \mathrm{~Hz}$ (RDE). Taken from Ref. 128. (The Royal Society of Chemistry).

"wired" and different crosslinking reactions were investigated.

A novel polyacrylamide-based redox gel was also prepared from copolymerisation and different catalyst systems were evaluated. A new ternary catalyst turned out to be the most effective for a simple and rapid gel preparation ${ }^{130}$.

Substantially larger currents were achieved with a polycationic redox hydrogel such as derivatized poly(allylamine $)^{131}$. Ferrocene carboxyaldehyde was initially attached to the polymer and the resulting redox polymer was further crosslinked with GOx via epichlorohydrin, see Fig. 4.

A typical catalytic wave is depicted in Fig. 5 in comparison with the cyclic voltammetry of the redox polymer in glucose free solution.

It should be noted the coincidence of the catalytic half wave potential with the redox potential of the mediator

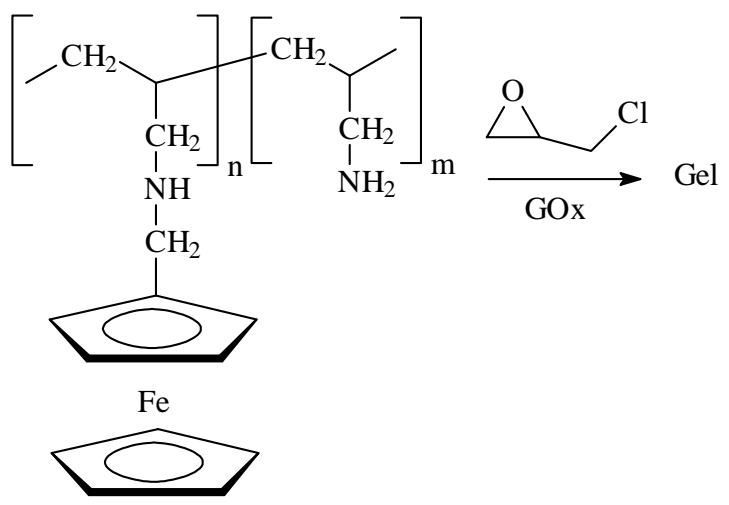

Figure 4. Ferrocene-poly(allylamine) crosslinked with GOx via epichlorohydrin to yield the redox hydrogel. (ratio n:m is 1:10). From Ref. 133 (Royal Society of Chemistry)

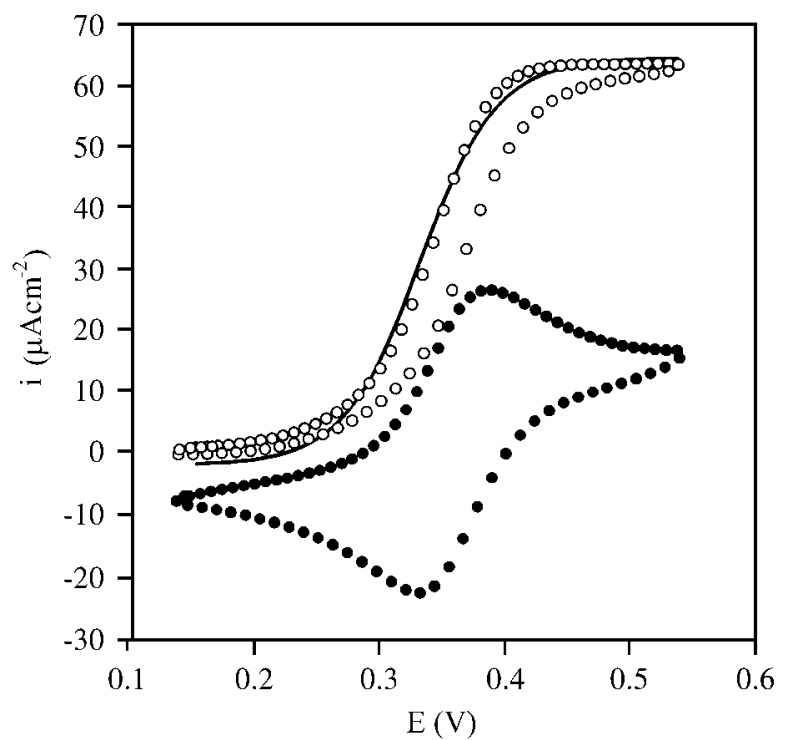

Figure 5. Catalytic wave for glucose oxidation in $50 \mathrm{mM}$ phosphate buffer $\mathrm{pH} 7.1$ and $0.1 \mathrm{M} \mathrm{KNO}_{3}$ at a Fc-PAA-GOx hydrogel modified electrode $\left(\bullet\right.$ ) glucose free solution $10 \mathrm{mV} \mathrm{s}^{-1}$ and (o) $0.1 \mathrm{M}$ glucose solution $5 \mathrm{mV} \mathrm{s}^{-1}$. Solid line corresponds to best fit to Eq. 8. (see text).

polymer. The catalytic wave was calculated according to Eq. $8^{131}$ :

$$
\mathrm{I}_{\mathrm{cat}}=\frac{2 \mathrm{FA} \sqrt{2 k \mathrm{D}_{\mathrm{e}} \mathrm{C}_{\mathrm{ET}}} \mathrm{C}_{\mathrm{T}} \exp \left[\beta \frac{\mathrm{F}}{\mathrm{RT}}\left(\mathrm{E}-\mathrm{E}^{\mathrm{o}^{\prime}}\right)\right]}{1+\exp \left[\beta \frac{\mathrm{F}}{\mathrm{RT}}\left(\mathrm{E}-\mathrm{E}^{\mathrm{o}^{\prime}}\right)\right]}
$$

where $\mathrm{E}=0.36 \mathrm{~V} v s . \mathrm{SCE}$ is the formal redox potential of the ferrocene/ferricinium couple in the polymer, obtained from the cyclic voltammetry, $\beta$ takes into account the interaction between redox centres and $\mathrm{k}=\mathrm{k}_{1} \mathrm{k}_{2} /\left(\mathrm{k}_{1}+\mathrm{k}_{2}\right)^{128}$.

The dependence of the catalytic current with substrate concentration can be shown with a typical calibration curve, Fig. 6. A good fit with Eq. 9 can be seen for jcat,max= $59.5 \pm 3.8 \mathrm{~mA} \mathrm{~cm}^{-2}$ and $\mathrm{Ks}^{\prime}=10.9 \pm 2.9 \mathrm{mM}$.

$$
\mathrm{I}_{\mathrm{cat}}=2 \mathrm{FA} \sqrt{\frac{2 \mathrm{C}_{\mathrm{T}} \mathrm{D}_{\mathrm{e}} k_{c a t} \mathrm{C}_{\mathrm{ET}}}{1+\frac{\mathrm{K}_{\mathrm{s}}}{\mathrm{C}_{\mathrm{s}}}}}
$$

Poly(allylamine) was also modified with $\left[\mathrm{Ru}\left(\mathrm{NH}_{3}\right)_{5}\right.$ py $]^{2 / 3+}$ and $\left[\mathrm{Fe}(\mathrm{CN})_{5} \text { py }\right]^{3 / 2-}$ showing three dimensional charge propagation ${ }^{132}$. However, a catalytic response was only obtained with positively charged ruthenium complex in spite of the large redox potential driving force of $\left[\mathrm{Fe}(\mathrm{CN})_{5} \mathrm{py}\right]^{3 / 2-}$.

Viscoelastic changes at redox modified hydrogels were studied with ferrocene poly(allylamine). Fast measurements in non-steady state experiments were performed with a quartz crystal microbalance. Deconvolution of both rigid mass $(\Delta \mathrm{m})$ and viscous resistance $(\mathrm{R})$ contributions to 


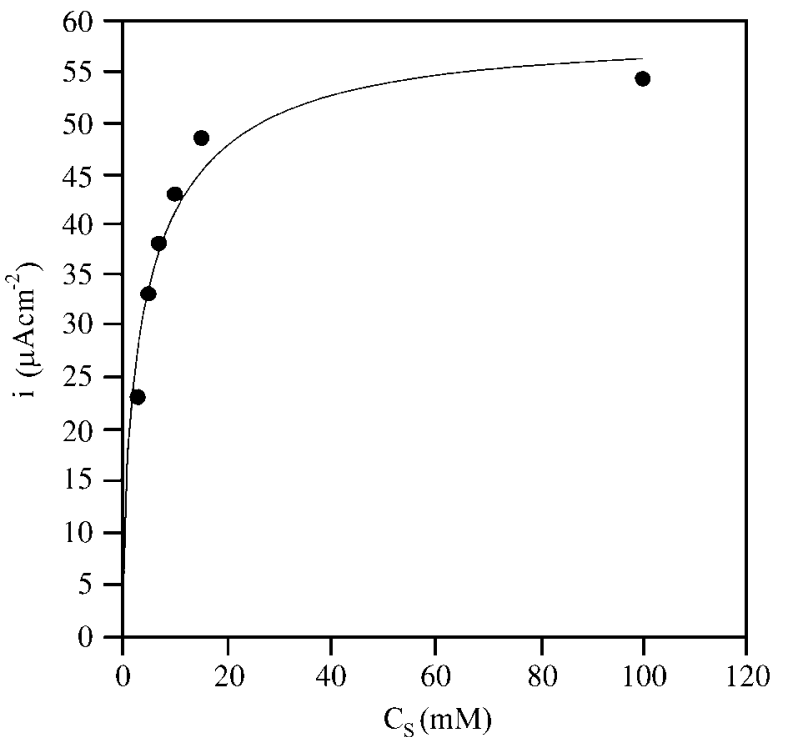

Figure 6. Steady state catalytic currents for substrate oxidation catalysed by Fc-PAA-GOx hydrogel in $0.1 \mathrm{M} \mathrm{KNO}_{3}$ and $20 \mathrm{mM}$ phosphate buffer of $\mathrm{pH} 7$ for different glucose concentrations $(\bullet)$. Solid line corresponds to best fit to Eq. 9 (see text).

$\Delta \mathrm{f}$ can be achieved with simultaneous cyclic voltammetric measurements ${ }^{133}$.

A different alternative was proposed by Oyama et al. ${ }^{134}$ for the entrapment of a redox enzyme in a thermoshrinkable redox polymer. In this case a cold aqueous solution of polymer and enzyme was placed on the electrode and the resulting mixture becomes insoluble for temperatures higher than the separation temperature $\left(\mathrm{ca} .20^{\circ} \mathrm{C}\right)$.

A multilayer film consisting of mediator and enzyme was prepared on a gold electrode. In this case a ferrocene derivative, used as electron mediator, and glucose oxidase were covalently bound employing glutaraldehyde as crosslinking agent ${ }^{135}$.

Another attractive and promising strategy is to immobilize one ${ }^{136,137}$ or several enzyme layers ${ }^{138}$ to modified electrodes using self assembly monolayers. In this way Willner et al. achieved electrical communication for various layers of GOx when developing organized networks on a self assembled monolayer of functionalized thiols on gold electrodes ${ }^{138}$.

Layer by layer self assembly of cationic redox polymer and GOx was presented as an integrated chemical system for biosensor design. Gold electrodes were initially thiolmodified and succesive immersion in ferrocene polymer and enzyme solutions allows the formation of multilayered structures ${ }^{139}$.

The idea of controlled spatial arragments of enzyme monolayers was initially achieved with an antigen-antibody immobilization procedure ${ }^{140}$. In this case catalytic response was evaluated by employing a soluble redox mediator. The antigen-antibody technique showed excellent results on account of catalytic response and stability.

This immunological procedure was extended up to 10 enzyme monolayers so as to obtain larger enzyme films ${ }^{141}$. A slight modification of this technique allowed the selective inactivation of any enzyme layer. The catalytic currents were analyzed in terms of the number of active and inactivated enzyme layers and mediator concentration. A constant value measured for each enzyme layer thickness proves that a high degree of spatial order is achieved in this step by step construction.

A full description of homogeneous kinetics and kinetic characterization of the antigen-antibody spatially ordered catalytic enzyme assemblies can be found in a recent review article by Saveant et al. ${ }^{142}$

A comprehensive theoretical study of diffusion and kinetics in amperometric electrodes in which both the enzyme and the mediator are confined within a film at the electrode surface was presented by Bartlett and Pratt ${ }^{143}$. A case diagram with several limiting cases is described for approximate analytical solutions under steady state conditions and an approximate analytical expression for the current response has been obtained for each limiting kinetic case.

A new insight into homogeneous enzyme catalysis was presented by Saveant et al. ${ }^{144}$ The various protonated forms of the flavin in GOx at the three succesive oxidation states are taken into account. Therefore significant variations with $\mathrm{pH}$ are detected when analyzing the catalytic response as a function of $\mathrm{pH}$.

Cyclic voltammetric experiments were also done in order to evaluate chiroselective electron transfer, previously reported for homogeneous mediated enzyme catalysis ${ }^{145}$. In this way, catalytic curves were studied with two enantiomeric forms of a ferrocene derivative giving equal catalytic response. The authors therefore concluded that the electron transfer reaction is not chiroselective ${ }^{146}$.

Consecutive enzymatic reactions can be applied to amperometric sensor design. These multienzyme sensors can be developed by immobilizing several enzymes in redox polymer films attached to solid electrodes. A simple device can involve co-immobilization of peroxidase and a peroxide producing oxidase such as glucose oxidase as shonw ing Fig. 7. In this case glucose can be either detected via both a monoenzyme scheme (Eqs. 1 to 4 ) or a bienzyme scheme where the following reaction is catalysed by GOx:

$$
\text { Glucose }+\mathrm{O}_{2} \longrightarrow \text { gluconic acid }+\mathrm{H}_{2} \mathrm{O}_{2}
$$

and the reaction product, $\mathrm{H}_{2} \mathrm{O}_{2}$, is further decomposed by horseradish peroxidase according to Eqs. 5 to 7 . At positive potentials Eqs. 1 to 4 take place whereas at much lower potentials the bienzyme scheme is involved.

Several multienzyme sensors have been reported by immobilization of enzymes in a crosslinked redox polymer. 


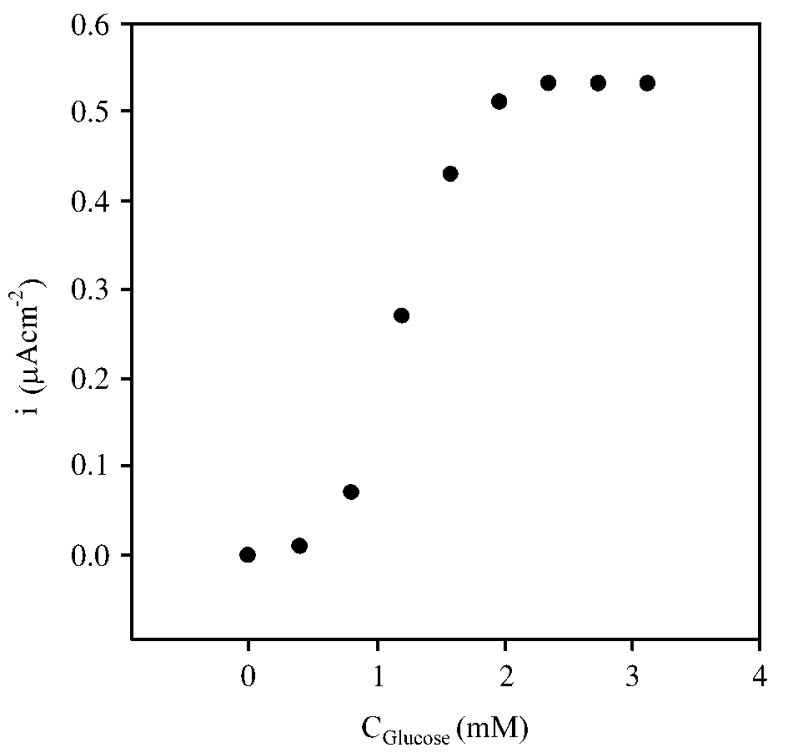

Figure 7. Steady state current for glucose oxidation at a bilayer enzyme electrode Fc-PAA-GOx-HRP in $0.1 \mathrm{M} \mathrm{KNO}_{3}$ and $50 \mathrm{mM}$ phosphate buffer of $\mathrm{pH} 6.7, \mathrm{O}_{2}$ saturated solution. $\mathrm{E}=0.05 \mathrm{~V} v \mathrm{~s}$. SCE.

Most of these sensors involve wired peroxidase and several oxidases such as lactate, alcohol and glucose oxidases ${ }^{147-150}$.

A novel four layer structure was reported for a glucose and lactate sensor based on wired thermostable soybean peroxidase. This device employed an osmium redox polymer as redox mediator and exhibited stable output at $37^{\circ} \mathrm{C}$ for several days ${ }^{151}$.

The feasibility of designing trienzyme electrodes where the enzymes are immobilized in a redox polymer matrix was reported by Michael et al. In this work the osmium redox polymer was crosslinked in the presence of choline oxidase, horseradish peroxidase and acetylcholinesterase and relatively low response to acetylcholine solutions was observed $^{152}$.

\section{References}

1. Thompson, M.; Krull, V.J. Anal. Chem. 1991, 63, 393A.

2. Göpel, W.; Schierbaum, K.D. "Sensors. A Comprehensive Survey", in Chemical and Biochemical Sensors, Part I. p. 2. Göpel, W.; Hesse, J.; Zemel, J.N. Eds., VCH, 1991, Vol. 2.

3. Osborn, J.A.; Yacynych, A.M.; Roberts, D.C. Anal. Chim. Acta 1986, 183, 287.

4. Tor, R.; Freeman, A. Anal. Chem. 1986, 58, 1042.

5. Turner, A.P.F. "Redox mediators and their application in amperometric sensors", in Analytical uses of immobilized biological compounds for detection, medical and industrial uses, Guilbault, G.G.; Mascini, M., Eds., D.Reidel Publishing Company, 1988, p. 131 .
6. Bard, A.J.; Faulkner, L.R. In Electrochemical Methods, Wiley, New York, 1980.

7. Mosbach, K.; Danielsson, B. Biochim. Biophys. Acta 1974, 364, 140.

8. Danielsson, B.; Mosbach, K. "Enzyme Thermistors", in Methods in enzymology, Colowick, S.P.; Kaplan, N.O.; Mosbach, K., Eds.; San Diego: Academic Press, 1988, vol.137, 181.

9. Ngeh Ngwainbi, J.; Foley, P.H.; Kuan, S.S.; Guilbault, G.G. J. Am. Chem. Soc. 1986, 108, 5444.

10. Wilchek, M.; Bayer, E.A. Anal. Biochem. 1988, 171, 1 .

11. Guilbault, G.G. Bio/Technology 1989, 7, 349.

12. Hillman, R.A.; Loveday, D.C.; Swann, M.J.; Bruckenstein, S.; Wilde, P.C. In Biosensors and Chemical sensors. Optimizing performance through polymeric materials, Edelman, P.G.; Wang, J., Eds., ACS Symposium series, 1992, 150.

13. Wolfbeis, O.S.; Weis, L.J.; Leiner, M.J.P.; Ziegler, W.E. Anal. Chem. 1988, 60, 2028.

14. Luo, S.; Walt, D.R. Anal. Chem. 1989, 61, 1069.

15. Hitchman, M.L.; Hill, H.A.O. Chemistry in Britain, 1986, 1117.

16. Metzler, D.E. Biochemistry, Academic Press, New york, Int. End. 1977, 478.

17. Stankovic, M.T.; Schopfer, L.M.; Massey, V. J. Biol. Chem. 1979, 253, 4971.

18. Ijeda, T.; Kobayashi, D.; Matsushita, F.; Sagara, T.; Niki, K. J. Electroanal. Chem. 1993, 361, 221.

19. Marko-Varga, G.; Appelquist, R.; Gorton, L. Anal. Chim. Acta 1986, 179, 371.

20. Jones, M.N.; Manley, P.; Wilkinson, A. Biochem. J. 1982, 203, 285.

21. Frederick, K.R.; Tung, J.; Emerick, R.S.; Masiarz, F.R.; Chamberlain, S.H.; Vasavada, A.; Rosenberg, S.; Chakraborty, S.; Schopfer, L.M.; Massey, V. J. Biol. Chem. 1990, 265, 3793.

22. Hayashi, S.; Nakamura, S. Biochem. Biophys. Acta 1981, 657, 40.

23. Hecht, H.J.; Kalisz, H.M.; Hendle, J.; Schimd, R.D.; Schomburg, D. J. Mol. Biol. 1993, 229, 153.

24. Kleppe, K. Biochemistry 1966, 5, 139.

25. Aleksandrovskii, Y.A.; Bezhikina, L.V.; Rodionov, Y.V. Biokhimiya 1981, 4, 708.

26. Schläpfer, P.; Mindt, W.; Racine, P.H. Clinica Chim. Acta 1974, 57, 283.

27. Wilson, R.; Turner, A.P.F. Biosens. \& Bioelectronics 1992, 7, 165.

28. Turner, A.P.F. "Amperometric Biosensors based on mediator modified electrodes", in Methods in enzymology, Colowick, S.P.; Kaplan, N.O.; Mosbach, K., Eds.; San Diego, Academic Press, 1988, vol. 137, 90. 
29. Cass, A.E.G.; Davis, G.; Francis, G.D.; Hill, H.A.O.; Aston, W.J.; Higgins, I.J.; Plotkin, E.V.; Scott, L.D.L.; Turner, A.P.F. Anal. Chem. 1984, 56, 667.

30. Frew, J.E.; Hill, H.A.O. Phil.Trans.R.Soc.Lond.B 1987, 316, 95.

31. Liaudet, E.; Battaglini, F.; Calvo, E.J. J.Electroanal. Chem. 1990, 293, 55.

32. Battaglini, F.; Calvo, E.J. J.Electroanal.Chem. 1990 , 280, 443.

33. Crumbliss, A.L.; Hill, H.A.O.; Page, D.J. J. Electroanal. Chem. 1986, 206, 327.

34. Bourdillon, C.; Lortie, R.; Laval, J.M. Biotechnol. Bioeng. 1988, 31, 553.

35. Williams, D.; Doig, A.; Korosi, A. Anal.Chem. 1970, $42,118$.

36. Heller, A. Acc.Chem.Res. 1990, 23, 128.

37. Degani, Y.; Heller, A. J. Am. Chem. Soc. 1988, 110, 2615.

38. Schuhmann, W.; Ohara, T.J.; Schmidt, H.L.; Heller, A. J. Am. Chem. Soc. 1991, 113, 1394.

39. Heller, A. J. Phys. Chem. 1992, 96, 3579.

40. Bartlett, P.N.; Bradford, V.Q.; Whitaker, R.G. Talanta 1991, 38, 57.

41. Bartlett, P.N.; Whitaker, R.G.; Green, M.J.; Frew, J.E. J. Chem. Soc. Chem.Commun. 1987, 103.

42. Szentrimay, R.; Yeh, P.; Kuwana, T. In Electrochemical studies of biological systems; Sawyer, D., Ed., ACS, Washington DC, 1977, 143.

43. Badia, A.; Carlini, R.; Fernandez, A.; Battaglini, F.; Mikkelsen, S.R.; English, A.M. J. Am. Chem. Soc. 1993, 115, 7053 .

44. Bartlett, P.N.; Booth, S.; Caruana, D.J.; Kilburn, J.D.; Santamaria, C. Anal. Chem. 1997, 69, 734.

45. Albery, W.J.; Bartlett, P.N.; Craston, D.H. J. Electroanal. Chem. 1985, 194, 223.

46. Cenas, N.K.; Kulys, J.J. Bioelectrochem.Bioenerg. 1981, 8, 103.

47. Albery, W.J.; Bartlett, P.N.; Driscoll, B.J. J. Electroanal. Chem. 1992, 323, 77.

48. Bartlett, P.N.; Tebbutt, P.; Whitaker, R.G. Prog. Reaction Kinetics 1991, 16, 55.

49. Mc Lendon, G. Acc. Chem. Res. 1988, 21, 160.

50. Ikeda, T.; Katasho,I.; Kamer, M.; Senda, M. Agric. Biol. Chem. 1984, 48, 1969.

51. Szucs, A.; Hitchens, G.D.; Bockris, J.O’M. Bioelectrochem. Bioenerg. 1989, 21, 133.

52. Szucs, A.; Hitchens, G.D.; Bockris, J.O’M. J. Electrochem. Soc. 1989, 136, 3748.

53. Miyawaki, O.; Wingard, L.B.Jr. Biochim. Biophys. Acta 1985, 838, 60.

54. Narasimhan, K.; Wingard, L.B.Jr. J. Mol. Catalysis 1986, 34, 263.

55. Narasimhan, K.; Wingard, L.B.Jr. Anal. Chem. 1986, 58, 2984.
56. Srere, P.A.; Uyeda, K. "Functional Groups on Enzymes Suitable for Binding to Matrices" in Methods in enzymology, Mosbach, K. Ed.; Academic Press, Inc., 1976, Vol 44, p. 11.

57. Clark, L.C.; Lyons, C. Ann. N.Y. Acad. Sci. 1962, 102, 29.

58. Updike, S.J.; Hicks, G.P. Nature 1967, 214, 986.

59. Guilbault, G.G.; Montalvo, J.G. J. Am. Chem. Soc. 1969, 91, 2164.

60. Guilbault, G.G.; Montalvo, J.G. J. Am. Chem. Soc. 1970, 92, 2533.

61. Guilbault, G.G.; Nanjo, M. Anal. Chem. 1974, 46, 1769.

62. Guilbault, G.G. "Enzyme Electrode Probes" in Methods in enzymology, Mosbach, K. Ed.; Academic Press, Inc., 1988, Vol 137, p. 90.

63. Beh, S.K.; Moody, G.J.; Thomas, J.D.R. Analyst 1989, 114, 1421.

64. Wingard, L.B.Jr.; Ellis, D.; Yao, S.J.; Schiller, J.G.; Liu, C.C.; Wolfson, S.K. Jr.; Drash, A.L. J. Solid Phase Biochemistry 1979, 4, 253.

65. Thomas, D.; Brown, G. Biochimie 1972, 54, 229.

66. Mell, L.D.; Maloy, J.T. Anal. Chem. 1975, 47, 299.

67. Yokoyama, K.; Tamiya, E.; Karube, I. J. Electroanal. Chem. 1989, 273, 107.

68. Yao, T. Anal. Chim. Acta 1983, 148, 27.

69. Wingard, L.B.Jr.; Cantin, L.A.; Castner, J.F. Biochim. Biophys. Acta 1983, 748, 21.

70. Castner, J.F.; Wingard, L.B.Jr. Biochemistry 1984, 23, 2203.

71. Shu, F.R.; Wilson, G.S. Anal. Chem. 1976, 48, 1679.

72. Battaglini, F.; Calvo, E.J. J. Chem. Soc. Faraday Trans. 1994, 90, 987.

73. Bartlett, P.N.; Birkin, P.R. Synthetic Metals 1993, 61, 15.

74. Bartlett, P.N.; Cooper, J. J. Electroanal. Chem. 1993, $362,1$.

75. Foulds, N.C.; Lowe, C.R. J. Chem. Soc. Faraday Trans. I 1986, 82, 1259.

76. Umaña, M.; Waller, J. Anal. Chem. 1986, 58, 2979.

77. Yabuki, S.I.; Shinohara, H.; Aizawa, M. J. Chem. Soc. Chem. Commun. 1989, 945.

78. Bartlett, P.N.; Whitaker, R.G. J. Electroanal. Chem. 1987, 224, 37.

79. Bartlett, P.N.; Ali, Z.; Eastwick Field, V. J.Chem.Soc. Faraday Trans. 1992, 88, 2677.

80. Deshpande, M.; Hall, E.A. Biosensors Bioelectron. 1990, 5, 431.

81. Kajiya, Y.; Tsuda, R.; Yonehama, H. J. Electroanal. Chem. 1991, 301, 155.

82. Taksuma, T.; Gordaira, M.; Watanabe, T. Anal. Chem. 1992, 64, 1183. 
83. Bentley, R. In The enzymes; Boyer, P.D.; Hardy, H.A.; Myrback, H. Eds., vol 7, Academic Press, New York, 1973, p. 567.

84. Dicks, J.M.; Hattori, S.; Karube, Y.; Turner, A.P.F.; Yokozawa, T. Ann. Biol. Clin. 1989, 47, 607.

85. Kajiya, Y.; Sugai, H.; Iwakura, C.; Yoneyama, H. Anal. Chem. 1991, 63, 49.

86. Schuhmann, W.; Kittsteiner-Eberle, R. Biosensors Bioelectronics 1991, 6, 263.

87. Belanger, D.; Nadreau, J.; Fortier, G. J. Electroanal. Chem. 1989, 274, 143.

88. Foulds, N.C.; Lowe, C.R. Anal. Chem. 1988, 60, 2473.

89. Bartlett, P.N.; Tebutt, P.; Tyrell, C. Anal. Chem. 1992, 64, 138.

90. Bartlett, P.N.; Whitaker, R.G. J. Electroanal. Chem. 1987, 224, 27

91. Scott, J.C.; Pfluger, P.; Krounbi, M.T.; Street, G.B. J. Phys. B. 1983, 28, 2140.

92. Pandey, P.C. J. Chem. Soc. Faraday Trans. I 1988, 84, 2259.

93. Bartlett, P.N.; Whitaker, R.G. Biosensors 1987/88, 3, 359.

94. Cooper, J.C.; Hall, E.A.H. Biosensors, 1992, 7, 473.

95. Bruno, F.; Pham, M.C.; Dubois, J.E. J. Electrochim. Acta 1977, 22, 451.

96. Bartlett, P.N.; Caruana, D.J. Analyst 1992, 117, 1287.

97. Sasso, S.V.; Pierce, R.J.; Walla, R.; Yacynych, A.M. Anal. Chem. 1990, 62, 1111.

98. Malitesta, C.; Palmisano, F.;Torsi, L.; Zambonin, P.G. Anal. Chem. 1990, 62, 2735.

99. Berners, M.O.M.; Boutelle, M.G.; Fillenz, M. Anal. Chem. 1994, 66, 2017.

100. Weetall, H.H. In Analytical uses of immobilized biological compounds for detection, medical and industrial uses; Guilbault, G.G.; Mascini, M. Eds., 1988, p.1, D.Reidel Publishing Company.

101. Cho, Y.K.; Bailey, J.E. Biotech. Bioeng. 1979, 21, 461.

102. Ianello, R,M.; Lindsay, T.J.; Yacynych, A.M. Anal. Chem. 1982, 54, 1098.

103. Ianello, R,M.; Lindsay, T.J.; Yacynych, A.M. Anal. Chem. 1982, 54, 1980.

104. Murray, R.W. In Electroanalytical Chemistry; Bard, A. Ed., Decker, New York, 1984, 191.

105. Andrieux, C.P.; Saveant, J.M. In Molecular Design of Electrode Surfaces, Murray, R.W., Ed., Wiley, 1992, 209.

106. Chambers, J.A.; Walton, N.J. J. Electroanal. Chem. 1988, 250, 417.

107. Hendry, S.P.; Cardosi, M.F.; Turner, A.P.F.; Neuse, E.W. Anal. Chim. Acta 1993, 281, 453.

108. Chen, C.J.; Liu, C.C.; Savinell, R.F. J. Electroanal. Chem. 1993, 348, 317.
109. Hale, P.D.; Inagaki, T.; Karan, H.I.; Okamoto, Y.; Skotheim, T.A. J. Am. Chem. Soc. 1989, 111, 3482.

110. Hale, P.D.; Bogulavs.ky, L.I.; Inagaki, T.; Karan, H.I.; Lee, H.S.; Skotheim, T.A.;Okamoto, Y. Anal. Chem. 1991, 63, 677.

111. Hale, P.D.; Bogulavs.ky, L.I.; Skotheim, T.A.; Liu, L.F.; Lee, H.S.; Karan, H.I.; Lan, H.L.; Okamoto, Y. In Biosensors and Chemical Sensors. Optimizing performance through polymeric materials, Edelman, P.G.; Wang, J., Eds. ACS Symp. Series 1992, p111.

112. Hale, P.D.; Lee, H.S.; Okamoto, Y. Anal. Lett. 1993, $26,1$.

113. Iijima, S.; Mizutani, F.; Yabuki, S.; Tanaka, Y.; Michihiko, A.; Katsura, T.; Hosaka, S.; Ibonai, M. Anal. Chim. Acta 1993, 281, 483.

114. Degani, Y.; Heller, A. J. Am. Chem. Soc. 1989, 111, 2357.

115. Pishko, M.V.; Katakis, I.; Lindquist, S.E.; Ye, L.; Gregg, B.A.; Heller, A. Angew. Chem. Int. Ed. Engl. 1990, 29, 82.

116. Katakis, Y.; Ling, Y.; Heller, A. J. Am. Chem. Soc. 1994, 116, 3617.

117. Gregg, B.A.; Heller, A. Anal.Chem. 1990, 62, 258.

118. Gregg, B.A.; Heller, A. J. Phys. Chem. 1991, 95, 5970.

119. Gregg, B.A.; Heller, A. J. Phys. Chem. 1991, 95, 5975.

120. Maidan, R.; Heller, A. J. Am. Chem. Soc. 1991, 113, 9003.

121. Maidan, R.; Heller, A. Anal. Chem. 1992, 64, 2889.

122. Katakis, I.; Heller, A. Anal. Chem. 1992, 64, 1008.

123. Ye, L.; Hammerle, M.; Olsthoorn, A.; Schuhmann, W.; Schmidt, H.; Duine, J.; Heller, A. Anal. Chem. 1993, 65, 238.

124. Kenausis, G.; Taylor, C.; Katakis, Y.; Heller, A. J. Chem. Soc. Faraday Trans. 1996, 92(20), 4131.

125. Ohara, T.J.; Rajagopalan, R.; Heller, A. Anal. Chem. 1993, 65, 3512.

126. Ohara, T.J.; Rajagopalan, R.; Heller, A. Anal. Chem. 1994, 66, 2451.

127. Csoregi, E.; Schmidtke, D.W.; Heller, A. Anal. Chem. 1995, 67, 1240.

128. Calvo, E.J.; Danilowicz, C.; Diaz,L. J. Chem. Faraday Soc. 1993, 89(2), 377.

129. Woodyear, T.; Rocca, P.; Lindsay, J.;Dror, Y.; Freeman, A.; Heller, A. Anal. Chem. 1995, 67, 1332.

130. Bu, H.; Mikkelsen, S.R.; English, A.M. Anal. Chem. 1995, 67, 4071.

131. Calvo, E.J.; Danilowicz, C.; Diaz, L. J. Electroanal. Chem. 1994, 369, 279.

132. Calvo, E.J; Danilowicz, C.; Diaz, L.; Etchenique, R. Anal. Chem. 1996, 68, 4186.

133. Calvo, E.J.; Danilowicz, C.; Etchenique, R. J. Chem. Faraday Soc. 1995, 91(22), 4083. 
134. Tatsuma, T.; Saito, K.; Oyama, N. Anal. Chem. 1994, 66, 1002.

135. Kuwabata, S.; Okamoto, T.; Kajiya, Y.; Yoneyama, H. Anal. Chem. 1995, 67, 1684.

136. Willner, I.; Riklin, A. Anal. Chem. 1994, 66, 1535.

137. Willner, I.; Katz, E.; Riklin, A.; Kasher, R. J. Am. Chem. Soc. 1992, 114, 10965.

138. Willner, I.; Riklin, A. Shoham, B.; Rivenzon, D.; Katz, E. Adv. Mater. 1993, 5, 912.

139. Hodak, J.; Etchenique, R.; Calvo, E.J.; Singhal, K.; Bartlett, P.N. Langmuir 1997, 140.

Bourdillon, C.; Demaille, C.; Gueris, J.; Moiroux, J.; Saveant, J.M. J. Am. Chem. Soc. 1993, 115, 12264.

141. Bourdillon, C.; Demaille, C.; Moiroux, J.; Saveant, J.M. J. Am. Chem. Soc. 1995, 17, 11499.

142. Bourdillon, C.; Demaille, C.; Moiroux, J.; Saveant, J.M. Acc. Chem. Res. 1996, 29, 529.

143. Bartlett, P.N.; Pratt, K.F.E. J. Electroanal. Chem. 1995, 397, 61.
144. Bourdillon, C.; Demaille, C.; Moiroux, J.; Saveant, J.M. J. Am. Chem. Soc. 1993, 115, 2.

145. Tibbon, S.; Katz, E.; Willner,I. J. Am. Chem. Soc. 1995, 117, 9925.

146. Alzari, P.; Anicet, N.; Bourdillon, C.; Moiroux, J.; Saveant, J.M. J. Am. Chem. Soc. 1996, 118, 6788.

147. Ohara, T.J.; Vreeke, M.S.; Battaglini, F.; Heller, A. Electroanalysis 1993, 5, 825.

148. Vijayakumar, A.R.; Csoregi, E.; Heller, A.; Gorton, L. Anal. Chim. Acta 1996, 327, 223.

149. Leca, B.; Morelis, R.M.; Coulet, P.R. Anal. Lett. 1996, 29, 661.

150. Vreeke, M.S.; Rocca, P. Electroanalysis 1996, 8, 55.

151. Kenausis, G.; Chen, Q.; Heller, A. Anal. Chem. 1997, 69, 1054.

152. Garguilo, M.G.; Huynh, N.; Proctor, A.; Michael, A.C. Anal. Chem. 1993, 65, 523. 